\title{
Influence of Grape Berry Age on Susceptibility to Guignardia bidwellii and Its Incubation Period Length
}

\author{
Lisa Emele Hoffman, Wayne F. Wilcox, David M. Gadoury, and Robert C. Seem
}

Department of Plant Pathology, Cornell University, New York State Agricultural Experiment Station, Geneva 14456. Current address of L. E. Hoffman: Department of Plant Pathology, University of California, Davis 95616.

Accepted for publication 4 June 2002.

\begin{abstract}
Hoffman, L. E., Wilcox, W. F., Gadoury, D. M., and Seem, R. C. 2002. Influence of grape berry age on susceptibility to Guignardia bidwellii and its incubation period length. Phytopathology 92:1068-1076.

The period of fruit susceptibility to Guignardia bidwellii (anamorph Phyllosticta ampelicida), the causal agent of grape black rot, was determined in the field. Intact fruit were inoculated weekly from bloom until 8 weeks later with a suspension containing $2 \times 10^{5}$ conidia per ml. Disease progress was monitored approximately every 2 days until 3 to 5 weeks after inoculation, depending on the year and variety. Fruit of Vitis $\times$ labruscana 'Concord' exhibited a period of maximum susceptibility from midbloom until 2 to 4 weeks later, although some berries became symptomatic when inoculated 4 to 5 weeks postbloom. Fruit of $V$. vinifera 'Chardonnay' and 'Riesling' exhibited a period of maximum susceptibility from midbloom until 3 to 5 weeks later, although some berries retained their susceptibility until 6 to 7 weeks postbloom. These suscep-

tible periods were approximately 2 to 4 weeks shorter than previously assumed. Fruit age at the time of inoculation affected the length of the incubation period (time from inoculation until symptom appearance). When the incubation period was defined in terms of degree hours (base = $0^{\circ} \mathrm{C}$ ) accumulated after inoculation, $\mathrm{DH}_{50}$ values (the number of degree hours required to reach $50 \%$ of final disease severity) increased by at least $50 \%$ as berries neared the end of their susceptible period. Newly symptomatic berries continued to appear for over 1 month after inoculation of older fruit. Thus, age-related or ontogenic, host resistance was manifested as both a decline in susceptibility and a significant increase in incubation period length. The control of black rot is likely to be improved by tailoring the intensity of fungicidal protection to the abbreviated period of fruit susceptibility defined in this study. Furthermore, the efficacy of management programs and the results of epidemiological studies are likely to be misinterpreted unless the variable effect of fruit age on incubation period length is recognized.
\end{abstract}

Black rot of grape, caused by the ascomycete Guignardia bidwellii (Ellis) Viala \& Ravaz (anamorph Phyllosticta ampelicida (Engleman) van der Aa), can lead to substantial yield losses in humid production regions when it is not effectively managed $(15,18-22)$. First collected in 1853 (19), G. bidwellii is native to North America, where it commonly is found on wild grape species $(19,20)$. Although the fungus can cause necrotic lesions on grape leaves and canes, economic damage occurs when fruit become rotted. On the fruit, symptoms progress from a diagnostic tan-tobrown spot, which quickly enlarges until the entire berry is rotten, culminating in a shriveled, chalky, black mummy from whence the disease takes it name.

Application of fungicides is the primary tactic used to control black rot in most commercial vineyards, although sanitation (i.e., removing infected debris from the trellis or the vineyard altogether) and good canopy management can augment the efficacy of these sprays $(8,9,20)$. However, to maximize the efficiency of these fungicides, it is necessary to know when and to what degree fruit are susceptible to infection by G. bidwellii as they develop. Furthermore, to correctly interpret the effects of specific control actions on disease progress during either research or production, it is critical to know precisely when disease symptoms will be expressed following infection (i.e., the duration of the incubation period). Otherwise, attribution of disease to specific weather events is impossible when multiple infection periods occur under field conditions.

Early researchers noted that only the young, aboveground portions of the vine were susceptible to infection by G. bidwellii

Corresponding author: L. E. Hoffman; E-mail address: lemhoffman@ucdavis.edu

Publication no. P-2002-0820-01R

(c) 2002 The American Phytopathological Society
$(15,21,22)$. Kuo and Hoch (14) characterized this ontogenic, or age-related resistance using grape leaves. They demonstrated that conidia were able to infect grape leaves of all ages, but were not able to colonize (i.e., infection pegs lacked subcuticular hyphae) leaves six or more nodes from the shoot tip. The occurrence of ontogenic resistance in the fruit has not been as well documented. Berries originally were thought to become resistant by veraison, i.e., the stage when berry color changes and softening occurs $(15,22)$. Later work with Vitis $\times$ labruscana 'Concord' similarly suggested that berries become highly resistant by approximately 10 weeks after bloom (4). Recommendations resulting from this work suggested that fungicidal protection of the fruit be maintained until 5\% sugar accumulation (20), or approximately midAugust in upstate New York. However, during a recent field study in Switzerland, new infections on V. vinifera 'Merlot' (11) did not occur after late July (approximately 6 weeks after bloom) despite the presence of weather conducive to infection. Similarly, in a previous New York study on 'Aurore' and 'Riesling' (5), black rot was controlled adequately when fungicide sprays were provided only through fruit set.

Previous literature indicates that black rot symptoms generally appear within 10 to 14 days after infection occurs, although this period is influenced by temperature $(1,21,24)$. Additional factors affecting incubation period length in other pathosystems include tissue age, inoculum concentration, and surface wetness duration during infection $(10,26)$, but these have not been studied with respect to black rot.

The objectives of this study were to determine under field conditions (i) the developmental period during which fruit of different Vitis cultivars are susceptible to infection by G. bidwellii, plus the effect of inoculum dose on its length; and (ii) the effect of fruit age on the incubation period of G. bidwellii. Abbreviated portions of this work have been published previously $(2,9)$. 


\section{MATERIALS AND METHODS}

Inoculation procedures. A small block consisting of ownrooted Vitis $\times$ labruscana 'Concord' and a separate vineyard containing V. vinifera 'Riesling' and 'Chardonnay', both located at the New York State Agricultural Experiment Station in Geneva, were utilized for the study. Approximately one-half the 'Riesling' and 'Chardonnay' vines were rooted on $3309 \mathrm{C}$ rootstock and the other half were propagated on a variety of rootstocks as part of a previous performance trial. All vines were cane-pruned by hand and trained to the Umbrella-Kniffen system. Ten clusters on each of four replicate vines were inoculated at various times after the start of bloom. The treatments were arranged in a completely randomized block design for 'Concord', but those on 'Chardonnay' and 'Riesling' were arranged in two complete blocks, one for vines on $3309 \mathrm{C}$ rootstock and the other for the mixture of rootstocks.

At dusk, clusters were inoculated until runoff with a spore suspension containing $2 \times 10^{5} \mathrm{G}$. bidwellii conidia per ml, using a hand-held Pre-val sprayer (Precision Valve Corporation, Yonkers, $\mathrm{NY}$ ), and enclosed in polyethylene bags overnight (approximately $12 \mathrm{~h}$ ) to maintain the surface wetness necessary for infection (23). In the first year of the experiment, temperature and relative humidity inside the bags were monitored with aspirating psychrometers using dry and wet bulb (wetted with a cotton wick) temperature probes (Model 107, Campbell Scientific, Logan, UT) mounted in a PVC pipe with a radiation shield and an aspiration fan located at the exhaust end. These instruments indicated that the relative humidity remained virtually $100 \%$ throughout the bagging period and that the temperature was sufficiently high to allow infection according to the criteria of Spotts (23). Water-inoculated check treatments were included for every cultivar at each inoculation time and randomized with the other treatments. All three cultivars were inoculated on the same dates.

To prepare inoculum, all isolates were grown on plates of 0.50strength potato dextrose agar (PDA) (19.5 g/liter $\mathrm{H}_{2} \mathrm{O}$, Difco Laboratories, Detroit, MI) for approximately 14 days at $25^{\circ} \mathrm{C}$ under fluorescent light. To harvest conidia, plates were flooded with $10 \mathrm{ml}$ of sterile, distilled water and incubated on the benchtop for $20 \mathrm{~min}$. The spore suspension was decanted and stirred for 10 min on a magnetic stir-plate to dissolve the cirrhi and thoroughly mix the spores. The suspension was adjusted to a final concentration of $2 \times 10^{5}$ conidia per $\mathrm{ml}$ with the aid of a hemacytometer. Isolates were maintained on water agar slants at room temperature under fluorescent light and transferred to new slants every 3 to 4 months. Isolates maintained in culture between seasons (approximately 8 months) were passaged through grape seedling leaves and reisolated from the black rot lesions prior to preparing inoculum. After each inoculation, the viability of the inoculum was confirmed by spraying conidia on four grape seedlings, enclosing them inside a plastic bag, and incubating them overnight in the greenhouse. Inoculated plants were incubated in the greenhouse approximately 2 weeks before they were assessed for necrotic lesions on the leaves.

To maintain healthy clusters for inoculation, fungicides to control powdery mildew (Uncinula necator) were applied to entire vines of $V$. vinifera 'Chardonnay' and 'Riesling' on a 14-day schedule from $10-\mathrm{cm}$ shoot growth until veraison. Resident inoculum of G. bidwellii was extremely low in the vineyard, and these sprays also provided control of natural black rot infections until fruit were ready for inoculating, as described below. Additional sprays of mefenoxam to control downy mildew (Plasmopara viticola) and iprodione or cyprodinil to control Botrytis bunch rot (Botrytis cinerea) were included as necessary. Gadoury et al. $(5,7)$ demonstrated that when grape clusters were bagged during myclobutanil applications and inoculated with $U$. necator $24 \mathrm{~h}$ later, powdery mildew severity was similar to that observed on unsprayed vines. Thus, to prevent maintenance fungicides from interfering with black rot development, the appropriate clusters were protected during fungicide applications within polyethylene bags that were removed approximately $1 \mathrm{~h}$ after the end of the spray application. In 1997 and 1998, when myclobutanil was the primary maintenance fungicide used, the clusters were bagged during
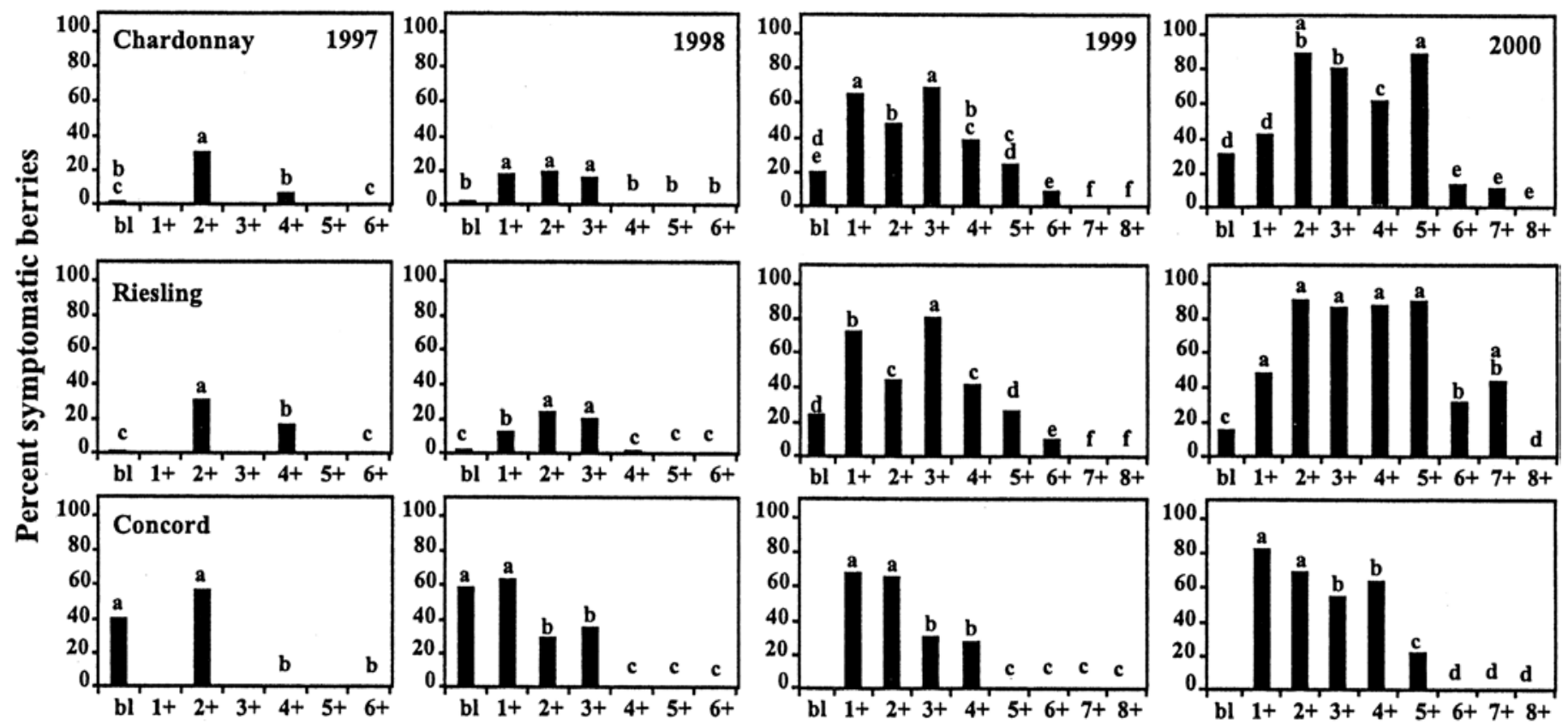

Inoculation timing (weeks relative to bloom)

Fig. 1. Susceptibility to Guignardia bidwellii among fruit of cvs. Chardonnay, Riesling, and Concord at different ages. Fruit were inoculated with a spore suspension containing $2 \times 10^{5}$ conidia per ml (i) every 2 weeks from bloom until 6 weeks later in 1997; (ii) weekly from bloom until 6 weeks later in 1998; or (iii) weekly from bloom until 8 weeks later in 1999 and 2000 (except for 'Concord' fruit which were first inoculated 1 week after bloom). Means (bars) not sharing a common letter are significantly different $(P \leq 0.05)$ as determined by the Waller-Duncan k-ratio $t$ test. 
sprays such that approximately 3 weeks transpired between the final application to an individual cluster and its inoculation. In 1999 and 2000, fenarimol and sulfur were used prebloom, whereas azoxystrobin and kresoxim-methyl, respectively, were the primary compounds used after bloom. Because of concern about the prolonged residual activity of the strobilurin fungicides, clusters were bagged during applications such that at least 3.5 to 4 weeks had elapsed between the time fungicide was last applied to the clusters and their inoculation. In 1999, unsprayed vines also were inoculated to confirm that residual fungicide activity was not interfering with black rot development, although development of severe powdery mildew on these unsprayed clusters precluded such evaluation. No vines were left unsprayed in 2000, but instead, clusters bagged such that at least 5 weeks between the last fungicide application and their inoculation were included as checks. Disease severity on these clusters was similar to that on clusters protected from fungicide sprays for 3.5 to 4 weeks before inoculation, suggesting little residual fungicide activity in either case.

Period of fruit susceptibility, 1997 and 1998 evaluations. Because 'Concord' bloomed several days before 'Chardonnay' and 'Riesling', the first inoculation date corresponded to $50 \%$ bloom for 'Concord' but only approximately 5\% for 'Chardonnay' and 'Riesling'. Fruit were then inoculated 2, 4, and 6 weeks later in 1997, and every week during this period in 1998. A single isolate, PY3 (isolated from infected leaves of Vitis riparia Michx. from Penn Yann, NY (13) and obtained from H. C. Hoch, Cornell University), was utilized in both years. The shortest latent period (defined as the time from infection until reproduction) reported in the literature for G. bidwellii is 10 days at an average temperature of $21^{\circ} \mathrm{C}$ (24). Therefore, to ensure that symptoms were a result of the original inoculation rather than subsequent secondary spread within the cluster, fruit were harvested 21 days after inoculation,

TABLE 1. Comparison of accumulated degree hours (DH) during the inoculation periods in 1999 and 2000

\begin{tabular}{lcc}
\hline & \multicolumn{2}{c}{ Accumulated $\mathrm{DH}\left(\right.$ base $\left.0^{\circ} \mathrm{C}\right) \times 100^{\mathrm{z}}$} \\
\cline { 2 - 3 } Time $($ week) & 1999 & 2000 \\
\hline $\mathrm{bl}$ & 0.0 & 0.0 \\
1 & 40.6 & 40.0 \\
2 & 68.1 & 69.6 \\
3 & 116.7 & 101.4 \\
4 & 145.8 & 133.9 \\
5 & 186.1 & 165.8 \\
6 & 227.4 & 203.4 \\
7 & 269.0 & 239.3 \\
8 & 300.4 & 276.9 \\
\hline
\end{tabular}

y Time with respect to $50 \%$ bloom of 'Chardonnay' and 'Riesling'. Specific designations correspond to the inoculation timings provided in Figure 1.

${ }^{\mathrm{z}}$ Degree hours accumulated between the 50\%-bloom inoculation date and those indicated. and the numbers of symptomatic and asymptomatic berries per cluster were counted. Analysis of variance (ANOVA) was performed on the percentage of symptomatic berries per cluster, with fruit age as the main treatment effect, and rootstock as the blocked variable where applicable. Population variances for each analysis of variance were homogeneous when checked with Hartley's test $(P<0.05,18)$; therefore ANOVA was performed using untransformed data for all analyses. The treatment means were separated using the Waller-Duncan k-ratio $t$ test. All statistical analyses were performed with SAS software (SAS Institute, Cary, NC).

Period of fruit susceptibility, 1999 and 2000 evaluations. In 1999 and 2000, 'Chardonnay' and 'Riesling' inflorescences were inoculated when approximately $50 \%$ of flowers were open using a mixture of equal quantities of conidia from three isolates of $G$. bidwellii. Fruit were inoculated every week thereafter for 7 weeks. 'Concord' inflorescences were not inoculated because they bloomed 1 week earlier than the two $V$. vinifera varieties, but fruit were inoculated weekly from 1 week after $50 \%$ bloom until 8 weeks later. In addition to PY3, two isolates were chosen arbitrarily from a group of sporulating isolates collected during a parallel study (9). In 1999, these were Dr985-3 and NaB984 (collected at the end of the 1998 field season in Dresden and Naples, NY, respectively). In 2000, NaB984 was replaced with Na001 (also collected in Naples at the start of the 2000 field season).

The number of symptomatic berries per cluster was counted nondestructively approximately every 2 days beginning 11 or 13 days after inoculation. Clusters were harvested 21 days after inoculation, and the number of symptomatic and asymptomatic berries on each was counted in the laboratory, unless little or no disease was apparent. In such cases, fruit were left to incubate on the vine for an additional week in 1999 and for an additional 2 weeks in 2000 before they were harvested and rated. In 2000, disease was determined every 3 to 4 days during those additional 2 weeks. Statistical analyses were performed as described above.

Effect of inoculum dose on fruit susceptibility. To investigate the effect of inoculum dose on the apparent onset of ontogenic resistance, 'Chardonnay' and 'Concord' fruit were also inoculated weekly with a suspension containing $6 \times 10^{6}$ conidia per $\mathrm{ml}$, from 3 or 4 through 8 weeks after bloom in 2000 and 1999, respectively. Ten clusters on each of four replicate vines per fruit age were inoculated. These higher inoculum-dose treatments were randomized as part of the larger experiment and were rated at the same time as the treatments that had been inoculated with $2 \times 10^{5}$ conidia per $\mathrm{ml}$. The means of individual high and low dose treatments were compared in paired $t$ tests using Minitab v. 12.0 (Minitab, Inc., State College, PA).

Effect of fruit age on incubation period length. To account for variation in temperature following individual inoculation dates, the resultant incubation periods were expressed in terms of degree hours, i.e., the sum of the mean hourly temperatures above a certain base value during the period in question. Mean hourly temperatures were determined by averaging the readings taken

TABLE 2. Effect of inoculum concentration on disease incidence when grape clusters were inoculated with conidia of Guignardia bidwellii at different stages of fruit development

\begin{tabular}{|c|c|c|c|c|c|c|c|c|}
\hline \multirow[b]{2}{*}{ Year } & \multirow[b]{2}{*}{ Cultivar } & \multirow[b]{2}{*}{ Inoculum concentration } & \multicolumn{6}{|c|}{ Berry age (weeks postbloom $)^{\mathrm{z}}$} \\
\hline & & & 3 & 4 & 5 & 6 & 7 & 8 \\
\hline \multirow[t]{3}{*}{1999} & Chardonnay & $2 \times 10^{5}$ & 68.5 & 38.2 & 23.4 & 7.6 & 0 & 0 \\
\hline & & $6 \times 10^{6}$ & & $73.3^{* *}$ & 12.9 & $0.1^{*}$ & 0 & 0 \\
\hline & & $6 \times 10^{6}$ & 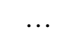 & 35.5 & $20.9^{*}$ & 0 & 0 & 0 \\
\hline \multirow[t]{2}{*}{2000} & Chardonnay & $2 \times 10^{5}$ & 82.0 & 61.7 & 92.6 & 12.5 & 10.4 & 0 \\
\hline & & $6 \times 10^{6}$ & 89.8 & 66.5 & 88.2 & 16.3 & 9.4 & 0 \\
\hline
\end{tabular}

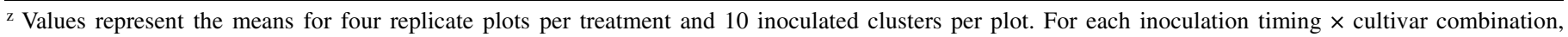
significant differences (two-sampled $t$-test) attributable to inoculum concentration are designated at $P \leq 0.05(*)$ or $P \leq 0.01(* *)$. 
each minute by a Campbell CR10 datalogger (Campbell Scientific, Logan, UT). To determine the base temperature above which degree hours would be accumulated, the minimum temperature for growth of $G$. bidwellii was established. Three 6-mm-diameter plugs of four arbitrarily chosen isolates were placed on petri plates containing 5\% malt agar (Difco Laboratories). Five replicate plates of each isolate were wrapped in foil and placed in cold rooms set at $2,4,6$, and $8^{\circ} \mathrm{C}$, within which Hobo dataloggers (Onset, Pocasset, MA) monitored the temperature. The mean colony diameters, measured 2, 3, and 4 weeks later, were regressed against time and the slope coefficient of each regression line was compared to 0 .

Because symptomatic berries from a single inoculation continued to appear over a period of 1 to 2 weeks following initial symptom expression, the incubation period was defined as the number of degree hours accumulated when $50 \%$ of final disease incidence was evident. For each replication of the cultivar $\times$ fruit age combination, the percentages of symptomatic berries during each disease assessment were transformed to probits (16) and regressed against the accumulated degree hours (DH). The $\mathrm{DH}_{50}$ was calculated from the resultant regression equations. The $95 \%$ confidence intervals for these values were calculated using the standard errors of the four replications. All regression analyses were performed using Microsoft Excel (Microsoft Corporation, Seattle, WA).

Effect of isolate variability on incubation period length. In 2000, additional 'Riesling' and 'Concord' fruit were inoculated weekly from 3 to 7 weeks after bloom, using each of the three isolates separately $\left(2 \times 10^{5}\right.$ conidia per $\left.\mathrm{ml}\right)$. As before, 10 clusters per vine were inoculated and the four replications per isolate were randomized within the larger study. These treatments were rated in the field and harvested at the same times as the main treatments. To determine if the isolate used for the inoculation affected disease incidence, the treatment means obtained during each individual disease assessment were subjected to an analysis of variance and were separated using the Waller-Duncan k-ratio $t$ test.
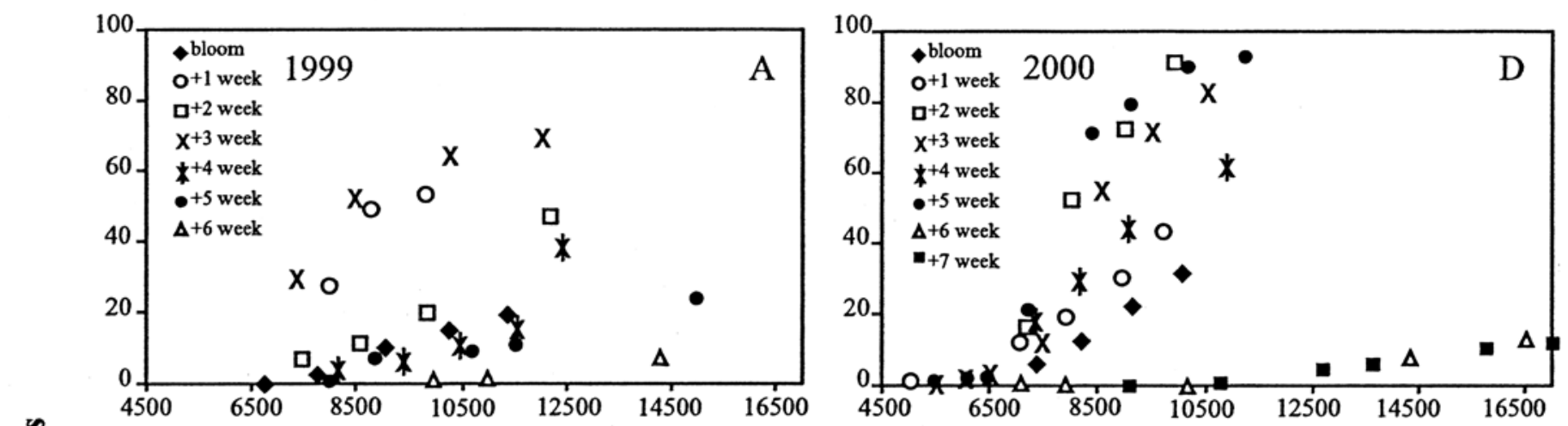

壱
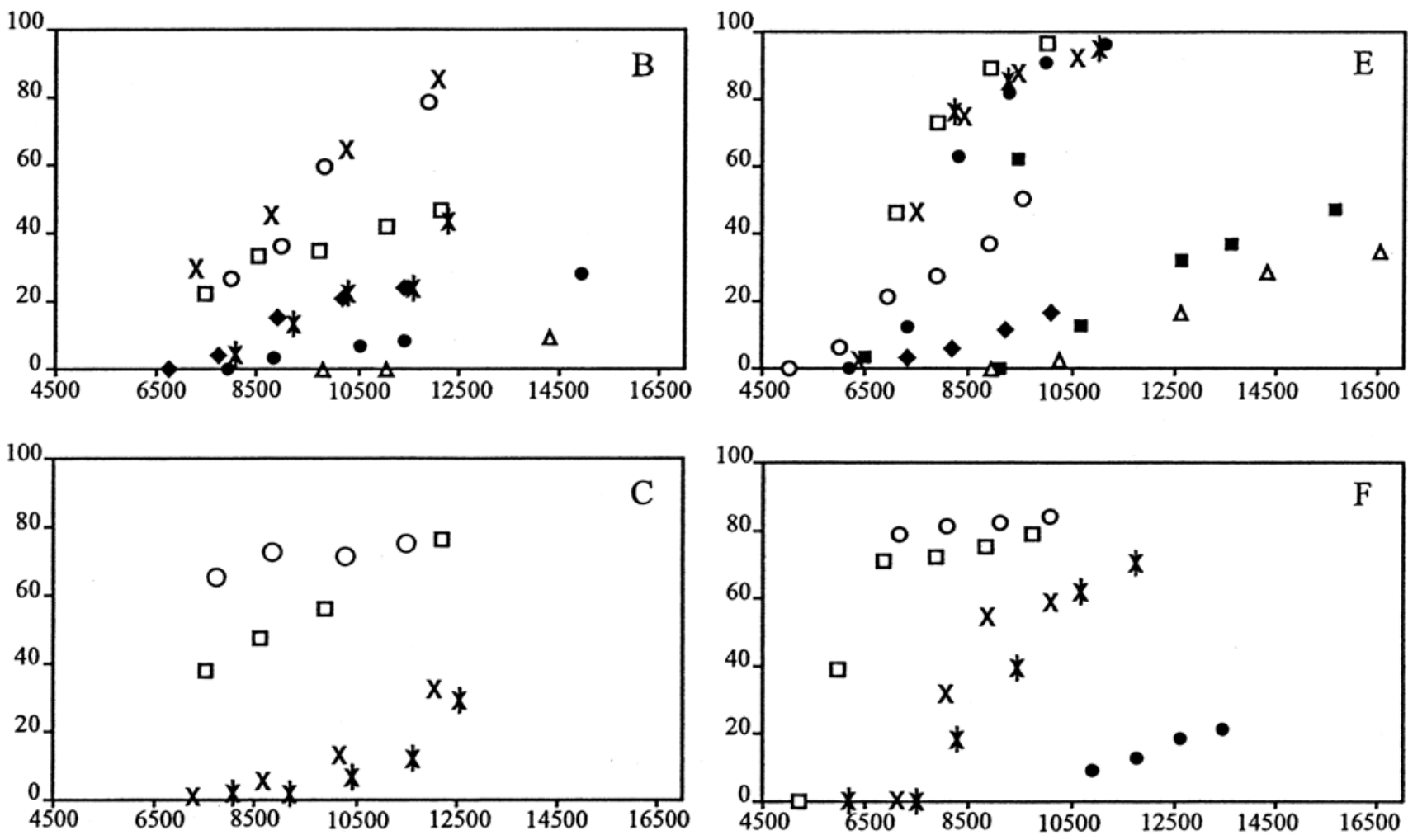

\section{Degree hours accumulated from inoculation (base $0^{\circ} \mathrm{C}$ )}

Fig. 2. Disease progress in 1999 and 2000 relative to the number of degree hours elapsed after inoculating clusters of A and D, 'Chardonnay', B and E, 'Riesling', and C and F, 'Concord' at weekly intervals beginning at bloom (or 1 week later for 'Concord'). Data points represent the mean frequencies of symptomatic berries on 10 clusters on each of four replicate vines per variety following each inoculation date. 
Additionally, the $\mathrm{DH}_{50}$ and the $95 \%$ confidence interval about the mean were calculated for each individual isolate $x$ fruit age combination.

\section{RESULTS}

Period of fruit susceptibility in 1997 and 1998. In 1997 and 1998 , fruit age at the time of inoculation significantly affected disease incidence for all cultivars $(P \leq 0.002$ to 0.0001$)$, but rootstock did not (except for 'Riesling' in 1997; $P \leq 0.07$ ). Therefore, the data for all rootstocks were combined in all analyses of the 'Riesling' and 'Chardonnay' data. In 1997, less than $1 \%$ of 'Chardonnay' and 'Riesling' berries that developed from flowers inoculated at early bloom (5\% of flowers open) developed black rot, indicating that flowers are not likely to become infected as long as the calyx cap remains intact (Fig. 1). The frequency of diseased berries increased to approximately $30 \%$ when clusters were inoculated 2 weeks later, but declined by one-half to three-fourths of this level when inoculations were made after another 2 weeks had elapsed. No symptomatic fruit resulted within 21 days of inoculations made 6 weeks past the $5 \%$ bloom stage. Approximately $50 \%$ of 'Concord' flowers were open on the day of the bloom inoculation, and nearly one-half the berries in these clusters developed black rot subsequently. Two-thirds of the berries developed black rot when clusters were inoculated 2 weeks later, but no fruit became symptomatic within 21 days of the inoculation made 6 weeks beyond the $50 \%$ bloom stage (Fig. 1).

In 1998, less than $1 \%$ of 'Chardonnay' and 'Riesling' berries were symptomatic within 21 days of the inoculations performed at $5 \%$ bloom or 4 weeks later, but approximately $20 \%$ of berries became symptomatic when inoculated 1 to 3 weeks after early bloom. No disease developed within 21 days when berries were inoculated 5 or 6 weeks after the start of bloom. 'Concord' fruit inoculated at a more advanced stage of bloom and 1 week later

TABLE 3. Mean slopes and $r^{2}$ values obtained when the percentage of diseased berries was regressed against the degree hours (base $0^{\circ} \mathrm{C}$ ) elapsed following inoculation of three grape cultivars at weekly intervals starting at bloom

\begin{tabular}{|c|c|c|c|c|c|}
\hline \multirow[b]{2}{*}{ Cultivar } & \multirow[b]{2}{*}{ Fruit age (weeks) ${ }^{\mathrm{w}}$} & \multicolumn{2}{|c|}{$1999^{x}$} & \multicolumn{2}{|c|}{$2000^{x}$} \\
\hline & & Slope & $r^{2}$ & Slope & $r^{2}$ \\
\hline \multirow[t]{8}{*}{ Chardonnay } & bl & 0.30 & 0.90 & 0.48 & 0.95 \\
\hline & 1 & 0.23 & 0.85 & 0.55 & 0.91 \\
\hline & 2 & 0.35 & 0.97 & 0.90 & 0.96 \\
\hline & 3 & 0.23 & 0.86 & 0.62 & 0.87 \\
\hline & 4 & 0.39 & 0.93 & 0.37 & 0.98 \\
\hline & 5 & 0.13 & 0.96 & 0.57 & 0.87 \\
\hline & 6 & $\ldots{ }^{y}$ & $\ldots{ }^{y}$ & 0.21 & 0.98 \\
\hline & 7 &.$^{z}$ & $\ldots^{z}$ & 0.14 & 0.94 \\
\hline \multirow[t]{8}{*}{ Riesling } & bl & 0.33 & 0.87 & 0.34 & 0.97 \\
\hline & 1 & 0.38 & 0.88 & 0.44 & 0.91 \\
\hline & 2 & 0.13 & 0.91 & 0.73 & 0.99 \\
\hline & 3 & 0.39 & 0.96 & 0.49 & 0.95 \\
\hline & 4 & 0.34 & 0.91 & 0.46 & 0.96 \\
\hline & 5 & 0.23 & 0.99 & 0.75 & 0.86 \\
\hline & 6 & $\ldots^{y}$ & $\ldots{ }^{y}$ & 0.24 & 0.91 \\
\hline & 7 & $\ldots^{\mathrm{z}}$ & $\ldots{ }^{z}$ & 0.23 & 0.95 \\
\hline \multirow[t]{5}{*}{ Concord } & 1 & 0.45 & 0.62 & $\ldots{ }^{y}$ & $\ldots^{\mathrm{y}}$ \\
\hline & 2 & 0.26 & 0.92 & $\ldots{ }^{\mathrm{y}}$ & $\ldots{ }^{\mathrm{y}}$ \\
\hline & 3 & 0.36 & 0.99 & 0.72 & 0.73 \\
\hline & 4 & 0.50 & 0.98 & 0.45 & 0.82 \\
\hline & 5 & $\ldots^{z}$ & $\ldots{ }^{z}$ & 0.25 & 0.95 \\
\hline
\end{tabular}

${ }^{\mathrm{w}}$ Fruit age at the time of inoculation in weeks relative to $50 \%$ bloom.

${ }^{\mathrm{x}}$ Mean slope and $r^{2}$ values resulted from the regression of the probittransformed percentage of symptomatic berries for each individual replication on the degree hours (base $0^{\circ} \mathrm{C}$ ) accumulated from the time of inoculation until each disease assessment.

${ }^{y}$ Treatments were not included in regression analyses as described in the text.

${ }^{\mathrm{z}}$ No disease resulted from the inoculation of fruit at the age indicated. were highly susceptible to infection, but disease incidence was reduced by one-half when inoculations were made 2 and 3 weeks after bloom. When clusters were inoculated 4 to 6 weeks after bloom, no disease was evident on berries harvested 21 days later (Fig. 1).

Period of fruit susceptibility in 1999 and 2000. As before, fruit age at the time of inoculation significantly $(P \leq 0.0001)$ affected the severity of fruit rot in both years, but rootstock did not. In 1999 and 2000, fruit were inoculated with three isolates of G. bidwellii rather than one, and older fruit were allowed to incubate on the vine longer than 21 days. As a result, the severity of
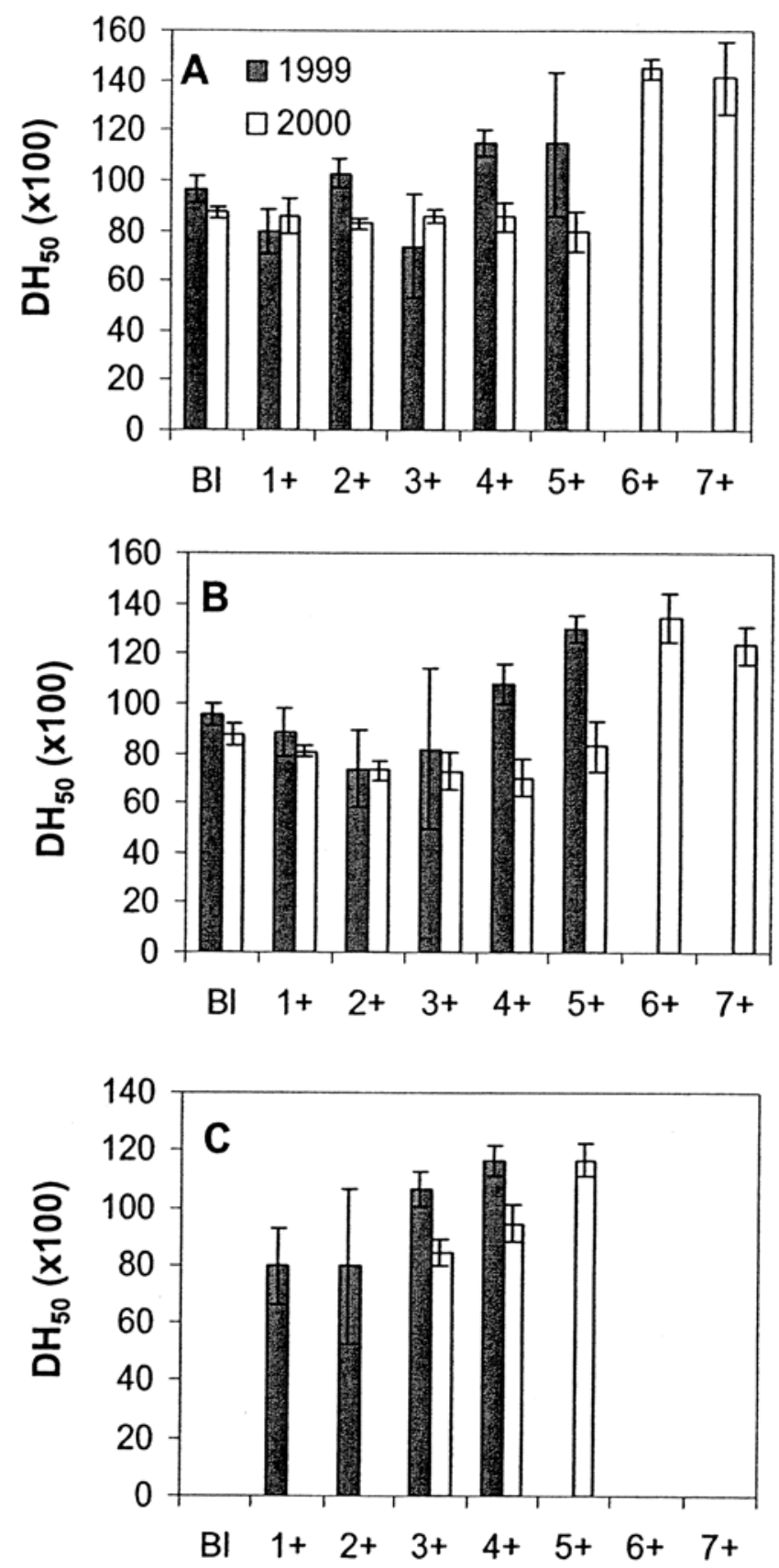

Fruit age at inoculation (weeks postbloom)

Fig. 3. Mean number of degree hours required to reach $50 \%$ of final disease incidence $\left(\mathrm{DH}_{50}\right)$ for fruit of $\mathbf{A}$, 'Chardonnay', B, 'Riesling', and $\mathbf{C}$, 'Concord' in 1999 and 2000. Error bars indicate the 95\% confidence intervals calculated about each mean using the standard error of the 4 replications per treatment. $\mathrm{DH}_{50}$ values were not calculated for 'Chardonnay' or 'Riesling' fruit inoculated $>5$ week postbloom in 1999 or 'Concord' fruit inoculated $<3$ week postbloom in 2000 , as described in the text. 
black rot and the period of fruit susceptibility for both $V$. vinifera cultivars increased relative to that in the two previous years (Fig. 1). In 1999, when 'Chardonnay' and 'Riesling' clusters were inoculated at approximately $50 \%$ bloom, 20 to $25 \%$ of berries developed black rot as compared to less than $1 \%$ when fruit were inoculated at $5 \%$ bloom in the two previous years. 'Chardonnay' fruit were most susceptible when inoculated from 1 to 4 weeks after this bloom stage: 40 to $70 \%$ of berries became symptomatic within 21 days of inoculation. When fruit were inoculated 5 and 6 weeks after bloom, only 11 and less than $1 \%$ of berries were symptomatic 21 days after inoculation, respectively (data not shown). Seven additional days of incubation, however, increased the frequency of symptomatic berries to 23 and $8 \%$, respectively (Fig. 1). The period of fruit susceptibility was very similar for 'Riesling', with maximum disease levels resulting from inoculations made 1 to 4 weeks after bloom. When 5- and 6-week-old fruit were inoculated, 8 and $0 \%$ of berries were symptomatic 21 days later, respectively (data not shown). However, incubation of the same clusters on the vine for another week increased these frequencies to 29 and $9 \%$, respectively (Fig. 1). The apparent period of susceptibility for 'Concord' fruit was 1 week longer than in 1998, but 2 weeks shorter than that observed for the two $V$. vinifera cultivars. 'Concord' fruit were most susceptible when inoculated 1 and 2 weeks after bloom, but these incidences of berry infection were reduced by more than one-half when clusters were inoculated 3 and 4 weeks after bloom (Fig. 1). Disease did not develop when 5- to 8-week-old fruit were inoculated, even though they were left on the vine until the fruit were harvested in early October.

In 2000, the period of fruit susceptibility for 'Chardonnay' and 'Riesling' was from bloom until 7 weeks later, and no disease occurred on vines inoculated 8 weeks after bloom despite leaving these fruit on the vine until they were harvested in early October
(Fig. 1). Approximately 30 and $40 \%$ of berries became symptomatic when inoculated at bloom and 1 week later, respectively, and the frequency of disease rose to 60 to $90 \%$ when fruit were inoculated from 2 to 5 weeks after bloom. When 6- and 7-weekold fruit were inoculated, $<1 \%$ of berries became symptomatic within 21 days after inoculation (data not shown), but after they were incubated for an additional 14 days on the vine 13 and $10 \%$ of berries were symptomatic, respectively (Fig. 1). 'Riesling' fruit exhibited a very similar pattern, although they appeared to be somewhat more susceptible 6 and 7 weeks after bloom. That is, when 6- and 7-week-old fruit were inoculated, 2 and $11 \%$ of berries were symptomatic 21 days later, whereas 32 and $45 \%$ of these respective berries were symptomatic when fruit were incubated for an additional 2 weeks (Fig. 1). In 2000, the period of fruit susceptibility was 1 week longer than in 1999. In 1999, 26,900 DH had accumulated from bloom until 7 weeks after bloom, but only $23,930 \mathrm{DH}$ had accumulated by this time in 2000 (Table 1). Fruit were not completely resistant until 8 weeks after bloom, at which time 27,690 DH had accumulated (Table 1). In 2000, Concord fruit remained highly susceptible to G. bidwellii through 4 weeks after bloom. Berry rot incidence was reduced sharply when 5-week-old fruit were inoculated, even though they were allowed to incubate 2 weeks longer than fruit inoculated on the earlier dates. No black rot developed on berries inoculated from 6- to 8-weeks postbloom, even after a 5-week incubation period (Fig. 1).

Effect of inoculum dose on the apparent onset of ontogenic resistance. The use of an inoculum dose of $6 \times 10^{6}$ rather than $2 \times$ $10^{5}$ conidia per $\mathrm{ml}$ occasionally lengthened the periods of maximum and overall fruit susceptibility, although not consistently between years or cultivars. For instance, in 1999, no symptomatic berries were observed when 5-week-old 'Concord' fruit were inoculated with the lower inoculum dose, but $21 \%$ of berries became symptomatic when the higher dose was used (Table 2).

TABLE 4. Variability in incubation period length on berries of Vitis vinifera 'Riesling' inoculated at different stages of development with three isolates of Guignardia bidwellii

\begin{tabular}{|c|c|c|c|c|c|c|}
\hline \multirow[b]{2}{*}{ Fruit age $\left(\right.$ week) ${ }^{\mathrm{w}}$} & \multirow[b]{2}{*}{ Days postinoculation $^{\mathrm{x}}$} & \multirow[b]{2}{*}{ DH accumulated $(\times 100)^{\mathrm{y}}$} & \multicolumn{4}{|c|}{ Percent symptomatic berries ${ }^{\mathrm{z}}$} \\
\hline & & & Mixture & DR5-3 & NA001 & PY3 \\
\hline 3 & $\begin{array}{l}12 \\
15 \\
18 \\
21\end{array}$ & $\begin{array}{r}58.9 \\
74.3 \\
90.0 \\
106.7\end{array}$ & $\begin{array}{l}0 \mathrm{~ns} \\
45 \mathrm{a} \\
86 \mathrm{a} \\
93 \mathrm{~ns}\end{array}$ & $\begin{array}{l}0 \\
67 \mathrm{a} \\
88 \mathrm{a} \\
95\end{array}$ & $\begin{array}{c}0 \\
41 \mathrm{a} \\
79 \mathrm{a} \\
95\end{array}$ & $\begin{array}{l}0 \\
0 \mathrm{~b} \\
49 \mathrm{~b} \\
89\end{array}$ \\
\hline 4 & $\begin{array}{l}12 \\
14 \\
16 \\
18 \\
21\end{array}$ & $\begin{array}{r}62.3 \\
73.4 \\
82.6 \\
91.8 \\
109.3\end{array}$ & $\begin{array}{c}0 \mathrm{~ns} \\
47 \mathrm{a} \\
72 \mathrm{a} \\
84 \mathrm{a} \\
95 \mathrm{a}\end{array}$ & $\begin{array}{c}0 \\
26 \mathrm{ab} \\
61 \mathrm{a} \\
73 \mathrm{~b} \\
78 \mathrm{~b}\end{array}$ & $\begin{array}{c}0 \\
26 \mathrm{ab} \\
60 \mathrm{a} \\
71 \mathrm{~b} \\
78 \mathrm{~b}\end{array}$ & $\begin{array}{c}0 \\
1 \mathrm{~b} \\
26 \mathrm{~b} \\
46 \mathrm{c} \\
83 \mathrm{~b}\end{array}$ \\
\hline 5 & $\begin{array}{l}11 \\
13 \\
15 \\
17 \\
19 \\
21\end{array}$ & $\begin{array}{r}61.2 \\
72.9 \\
83.7 \\
92.5 \\
102.1 \\
112.5\end{array}$ & $\begin{array}{l}0 \mathrm{~ns} \\
11 \mathrm{a} \\
62 \mathrm{a} \\
82 \mathrm{a} \\
91 \mathrm{~ns} \\
96 \mathrm{a}\end{array}$ & $\begin{array}{c}0 \\
9 \mathrm{a} \\
40 \mathrm{~b} \\
60 \mathrm{~b} \\
83 \\
91 \mathrm{ab}\end{array}$ & $\begin{array}{c}0 \\
9 \mathrm{a} \\
38 \mathrm{~b} \\
75 \mathrm{~b} \\
85 \\
92 \mathrm{ab}\end{array}$ & $\begin{array}{l}0 \\
0 \mathrm{~b} \\
7 \mathrm{c} \\
35 \mathrm{c} \\
70 \\
88 \mathrm{~b}\end{array}$ \\
\hline 6 & $\begin{array}{l}18 \\
21 \\
26 \\
29 \\
33\end{array}$ & $\begin{array}{r}90.1 \\
102.9 \\
132.1 \\
149.1 \\
165.0\end{array}$ & $\begin{array}{c}0 \mathrm{~ns} \\
2 \mathrm{c} \\
14 \mathrm{~b} \\
26 \mathrm{~b} \\
32 \mathrm{~b}\end{array}$ & $\begin{array}{c}0 \\
6 \mathrm{~b} \\
18 \mathrm{~b} \\
29 \mathrm{~b} \\
32 \mathrm{~b}\end{array}$ & $\begin{array}{c}0 \\
13 \mathrm{a} \\
37 \mathrm{a} \\
50 \mathrm{a} \\
54 \mathrm{a}\end{array}$ & $\begin{array}{c}0 \\
0 \mathrm{c} \\
9 \mathrm{~b} \\
17 \mathrm{~b} \\
24 \mathrm{~b}\end{array}$ \\
\hline 7 & $\begin{array}{l}19 \\
22 \\
26 \\
29 \\
33\end{array}$ & $\begin{array}{r}91.1 \\
107.5 \\
126.7 \\
136.3 \\
156.8\end{array}$ & $\begin{array}{l}0 \mathrm{~ns} \\
11 \mathrm{ab} \\
29 \mathrm{a} \\
33 \mathrm{a} \\
45 \mathrm{a}\end{array}$ & $\begin{array}{c}0 \\
19 \mathrm{a} \\
41 \mathrm{a} \\
47 \mathrm{a} \\
58 \mathrm{a}\end{array}$ & $\begin{array}{c}0 \\
13 \mathrm{ab} \\
36 \mathrm{a} \\
41 \mathrm{a} \\
57 \mathrm{a}\end{array}$ & $\begin{array}{l}0 \\
0 \mathrm{~b} \\
5 \mathrm{~b} \\
6 \mathrm{~b} \\
13 \mathrm{~b}\end{array}$ \\
\hline
\end{tabular}

${ }^{\mathrm{w}}$ Fruit age at the time of inoculation relative to $50 \%$ bloom.

${ }^{x}$ Timing of disease assessment in days postinoculation. Prior assessments are not shown if no disease was observed.

y Number of degree hours (base $0^{\circ} \mathrm{C}$ ) accumulated from the time of inoculation until the disease assessment indicated.

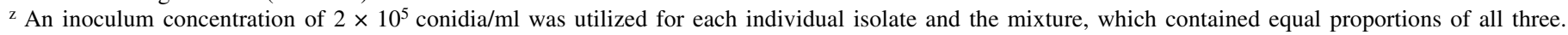
Treatment means within a row not followed by a common letter are significantly different $(P \leq 0.05)$ as determined in the Waller-Duncan k-ratio $t$-test. ns $=$ no significant differences among means. 
Similarly in 2000, when the lower dose was utilized, the incidence of symptomatic 'Concord' berries declined by $69 \%$ in response to the 5- versus 4-week postbloom inoculation. In contrast, the onset of ontogenic resistance during this period was much less apparent if the higher dose was used, i.e., the decline in the frequency of diseased berries was only $25 \%$ when comparing the same inoculation dates (Table 2). In both instances, the differences in disease severity with respect to inoculum dose were statistically significant $(P \leq 0.05$ and 0.01 , respectively). The only other statistically significant effect of inoculum dose occurred on 'Chardonnay' in 1999, when inoculations with the higher dose 4 weeks after bloom produced more disease, whereas the converse was true for inoculations made 6 weeks after bloom (Table 2).

Effect of fruit age on incubation period length. The minimum temperature for growth of the four isolates of G. bidwellii tested was between 4 and $6^{\circ} \mathrm{C}$. However, when sample regression analyses were performed with the field data to examine berry rot incidence as a function of degree hours, discernible differences were not evident when a base of either 0 or $6^{\circ} \mathrm{C}$ was used (data not shown). Therefore, for simplicity, a base of $0^{\circ} \mathrm{C}$ was used for all degree hour accumulations.

When the percentage of symptomatic berries was plotted against the degree hours accumulated between the corresponding inoculation and disease assessment dates, it was apparent that the incubation period for $G$. bidwellii increased as fruit aged. For instance, when 'Chardonnay' and 'Riesling' fruit were inoculated from bloom until 4 weeks later in 1999, symptoms were apparent by the disease assessment 13 days, or approximately 7,500 to $8,000 \mathrm{DH}$, after inoculation (Fig. 2A and B). However, when 5 and 6-week-old fruit were inoculated, the first symptoms were not apparent until the disease assessments 15 and 21 days, or 9,000 and $11,000 \mathrm{DH}$, after inoculation, respectively, at which time only 0.1 to $3 \%$ of berries were symptomatic. When 'Concord' fruit were inoculated 1 and 2 weeks after bloom, symptoms were apparent by the time 7,500 DH had accumulated (Fig. 2C). When 3- and 4-week-old fruit were inoculated, however, symptomatic berries were not apparent until the disease assessment 5 days or 8,500 and 9,500 DH after inoculation, respectively (Fig. 2C). A similar delay in symptom appearance was observed on the older fruit of all three cultivars in 2000 (Fig. 2D to F).

When the probit-transformed percentage of symptomatic berries was regressed against the number of degree hours accumulated after each inoculation in 1999 and 2000, the logistic regression model fit the data well: approximately $70 \%$ of $r^{2}$ values for the individual regression equations were greater than 0.90 and $95 \%$ were greater than 0.80 (Table 3). Because the 1999 assessments for 6-week-old 'Chardonnay' and 'Riesling' fruit contained only one data point where disease was observed (Fig. 2A and B), these treatments were dropped from the regression analyses; thus, each regression analysis was based on at least four data points. Oneand two-week-old Concord fruit were also dropped from the analysis in 2000, since disease developed rapidly and less than four points were available for the regression analysis (Fig. 2F).

The relationship between fruit age and incubation period length was similarly evident in comparisons of $\mathrm{DH}_{50}$ values. In 2000, as fruit of each cultivar aged, a sharp increase in $\mathrm{DH}_{50}$ values occurred (Fig. 3) at times corresponding to those at which the frequency of symptom development declined sharply (Fig. 1). For instance, the $\mathrm{DH}_{50}$ was typically between 8,000 and 9,000 when 'Chardonnay' and 'Riesling' fruit were inoculated from bloom until 5 weeks later, but increased to $>13,000$ when less-susceptible 6- and 7-week-old fruit were inoculated (Fig. 3A and B). On 'Concord', the $\mathrm{DH}_{50}$ similarly increased by almost $50 \%$ when less susceptible fruit were inoculated 5 weeks after bloom as compared to when highly susceptible 3 and 4-week-old fruit were inoculated (Figs. 1 and 3C).

In 1999 , the $\mathrm{DH}_{50}$ was between 8,000 and 10,200 when highly susceptible 'Chardonnay' fruit were inoculated from $50 \%$ bloom until 3 weeks later. As fruit susceptibility decreased with age, the $\mathrm{DH}_{50}$ increased to $>11,000$ when 4- and 5-week old fruit were inoculated (Fig. 3A). A similar trend was observed on 'Riesling' and 'Concord' fruit. When 'Riesling' fruit were inoculated from midbloom until 3 weeks later, the $\mathrm{DH}_{50}$ was between 7,400 and $9,500 \mathrm{DH}$, but increased to approximately 11,000 and $13,000 \mathrm{DH}$ when 4-and 5-week-old fruit were inoculated, respectively (Fig. 3B). The $\mathrm{DH}_{50}$ was $<8,000$ when 1- and 2-week-old 'Concord' fruit were inoculated, but $>10,000$ when significantly less-susceptible 3- and 4-week-old fruit were inoculated (Fig. 3C).

Effect of isolate variability on incubation period length. A longer incubation period was required for PY3 than the other two isolates (Tables 4 and 5). For instance, when 'Riesling' fruit were inoculated 3 weeks after 50\% bloom with isolate DR985-3 or NA001, symptomatic berries were first apparent during the assessment 15 days, or nearly 7,500 DH after inoculation. In contrast, disease was not observed until the assessment 18 days or 9,000 DH after inoculation with isolate PY3, when black rot inci-

TABLE 5. Variability in incubation period length on berries of Vitis $\times$ labruscana 'Concord' inoculated at different stages of development with three isolates of Guignardia bidwellii separately and as a mixture

\begin{tabular}{|c|c|c|c|c|c|c|}
\hline \multirow[b]{2}{*}{ Fruit age $\left(\right.$ week) ${ }^{\mathrm{w}}$} & \multirow[b]{2}{*}{ Days postinoculation $^{\mathrm{x}}$} & \multirow[b]{2}{*}{ DH accumulated $(\times 100)^{\mathrm{y}}$} & \multicolumn{4}{|c|}{ Percent symptomatic berries by isolate ${ }^{\mathrm{z}}$} \\
\hline & & & Mixture & DR5-3 & NA001 & PY3 \\
\hline 3 & $\begin{array}{l}15 \\
17 \\
19 \\
21\end{array}$ & $\begin{array}{r}72.9 \\
81.5 \\
90.4 \\
100.7\end{array}$ & $\begin{array}{l}1 \mathrm{~ns} \\
32 \mathrm{a} \\
55 \mathrm{a} \\
61 \mathrm{a}\end{array}$ & $\begin{array}{c}0 \\
29 \mathrm{a} \\
38 \mathrm{a} \\
55 \mathrm{ab}\end{array}$ & $\begin{array}{l}0 \\
24 \mathrm{ab} \\
42 \mathrm{a} \\
52 \mathrm{ab}\end{array}$ & $\begin{array}{c}0 \\
0 \mathrm{~b} \\
3 \mathrm{~b} \\
29 \mathrm{~b}\end{array}$ \\
\hline 4 & $\begin{array}{l}15 \\
17 \\
19 \\
21 \\
23\end{array}$ & $\begin{array}{r}74.3 \\
84.8 \\
95.6 \\
106.7 \\
118.9\end{array}$ & $\begin{array}{c}0 \mathrm{~b} \\
18 \mathrm{ab} \\
41 \mathrm{a} \\
63 \mathrm{a} \\
71 \mathrm{a}\end{array}$ & $\begin{array}{r}1 \mathrm{a} \\
34 \mathrm{a} \\
60 \mathrm{a} \\
75 \mathrm{a} \\
82 \mathrm{a}\end{array}$ & $\begin{array}{r}0 \mathrm{~b} \\
27 \mathrm{a} \\
58 \mathrm{a} \\
75 \mathrm{a} \\
80 \mathrm{a}\end{array}$ & $\begin{array}{r}0 \mathrm{~b} \\
0 \mathrm{~b} \\
7 \mathrm{~b} \\
24 \mathrm{~b} \\
40 \mathrm{~b}\end{array}$ \\
\hline 5 & $\begin{array}{l}18 \\
21 \\
23 \\
25 \\
27\end{array}$ & $\begin{array}{r}91.8 \\
109.3 \\
118.9 \\
127.3 \\
135.4\end{array}$ & $\begin{array}{c}0 \mathrm{~ns} \\
8 \mathrm{a} \\
13 \mathrm{ab} \\
18 \mathrm{ab} \\
22 \mathrm{~ns}\end{array}$ & $\begin{array}{c}0 \\
10 \mathrm{a} \\
16 \mathrm{a} \\
26 \mathrm{a} \\
31\end{array}$ & $\begin{array}{c}0 \\
8 \mathrm{a} \\
14 \mathrm{a} \\
22 \mathrm{a} \\
29\end{array}$ & $\begin{array}{l}0 \\
0 \mathrm{~b} \\
4 \mathrm{~b} \\
8 \mathrm{~b} \\
14\end{array}$ \\
\hline
\end{tabular}

${ }^{\mathrm{w}}$ Fruit age at the time of inoculation relative to $50 \%$ bloom.

${ }^{x}$ Timing of disease assessment in days postinoculation. Prior assessments are not shown if no disease was observed.

y Number of degree hours (base $0^{\circ} \mathrm{C}$ ) accumulated from the time of inoculation until the disease assessment indicated.

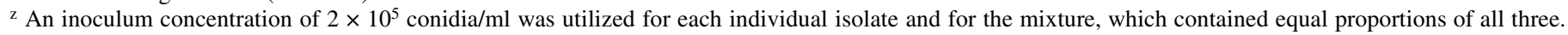
Treatment means within a row not followed by a common letter are significantly different $(P \leq 0.05)$ as determined in the Waller-Duncan k-ratio $t$ test. ns $=$ no significant differences among means. 
dence was only about one-half that on clusters inoculated with either DR985-3 or Na0001 (Table 4). Similarly, when 'Riesling' fruit were inoculated 6 and 7 weeks after bloom with either DR985-3 or Na0001, symptomatic berries were first evident 21 or 22 days, or between 10,000 and $11,000 \mathrm{DH}$, after inoculation; however, symptoms caused by PY3 were not evident until the disease assessment 26 days or approximately 12,000 DH after inoculation. A similar delay in the appearance of symptoms for PY3 relative to the other two isolates was also observed on 'Concord' at all fruit ages tested. For instance, when 3-, 4-, and 5-weekold fruit were inoculated with either DR5-3 or Na001, substantial fruit rot (i.e., $>1 \%$ symptomatic berries) became evident after 17, 17 , and 21 days of incubation, respectively, whereas symptoms caused by PY3 were not evident until the next disease assessment 2 days (1,000 DH) later (Table 5). Typically, mean disease incidence at the onset of symptom expression was significantly $(P=$ $0.05)$ less on clusters inoculated with PY3 than on those inoculated with the other two isolates, although these differences often were absent by the final disease assessment (Tables 4 and 5).

\section{DISCUSSION}

V. vinifera 'Riesling' and 'Chardonnay' berries were highly susceptible to G. bidwellii from midbloom until 4 to 5 weeks later, although some disease occurred in clusters inoculated 6 to 7 weeks postbloom. The period of maximum susceptibility for fruit of $V . \times$ labruscana 'Concord' was shorter, lasting only until 2 to 4 weeks after midbloom, although a few berries became diseased when inoculated 4 to 5 weeks postbloom. This period of fruit susceptibility is relatively consistent with that observed in Michigan by Ferrin and Ramsdell, who inoculated a limited number of 'Concord' shoots at various phenological stages with field-collected ascospores (3) or conidia (4) of the fungus. However, in contrast to results from the present study, these authors noted a distinct peak in susceptibility at the midbloom stage, and found that a small proportion of berries became symptomatic when inoculated with conidia through 10 weeks after bloom. It is not clear whether the differences between these earlier results and ours reflect different methodologies or differences in some environmental and/or biological factor(s) operative during the respective experiments.

Ontogenic resistance was manifested as both a decline in the percentage of berries that developed black rot after inoculation and an increase in the incubation period as fruit aged. This longer incubation period on older fruit, confounded by the even longer incubation period of isolate PY3 as compared to DR985-3 and NA001, was likely responsible for the much shorter period of fruit susceptibility observed when only isolate PY3 was used, and the final disease assessment was made 21 days after inoculation in 1997 and 1998, relative to 1999 and 2000 (inoculations with three isolates; final assessments 4 and 5 weeks later, respectively). Thus, the data from these first 2 years should be viewed as incomplete and merely supportive of the data from 1999 and 2000. The variability observed between PY3 and the other two G. bidwellii isolates may have been due to inherent differences among individuals within the species and/or because PY3 was cultured for a number of years prior to this study and yearly passaging through the host was not enough to maintain its original fitness. The 1-week difference in the temporal duration of the incubation period between 1999 and 2000 was apparently due to the colder season in 2000 and the subsequent delay in fruit maturation, since the development of ontogenic resistance was similar with respect to degree-hour accumulation in both seasons.

Field trials conducted in a vineyard consisting of the Vitis interspecific hybrid 'Aurore' demonstrated that applications of the fungicide myclobutanil, from immediately before bloom through 4 weeks later, provided virtually complete control of fruit rot when used in conjunction with good sanitation (i.e., removal of mummies from the trellis during dormant pruning) $(2,8,9)$. Con- sidering the period of susceptibility demonstrated in this present report, it is likely that the dissipation of activity from the final fungicide application coincided with the acquisition of high levels of ontogenic resistance around 5 to 6 weeks after bloom. Additional fungicide applications 6 weeks after bloom provided no benefit in this vineyard or in another vineyard of $V . \times$ labruscana 'Delaware', even though abundant inoculum of G. bidwellii was present at that time in the latter $(8,9)$. Although it previously has been suggested that fruit infections can occur until the onset of berry color (approximately 10 weeks after bloom in the Finger Lakes Region of NY) and that protective fungicides should be applied until fruit contain about 5\% sugar (20), our results suggest that the period of susceptibility and attendant need for fungicidal protection ends considerably sooner. These results are consistent with the findings of Jermini and Gessler (11), who noted no new infections from wetting periods that occurred $>6$ weeks after full bloom and of Gadoury et al. (6), who obtained little more black rot when fungicide sprays were terminated at fruit set than when protection was maintained until veraison. The latter authors, however, attributed their results to exhaustion of primary inoculum following bloom rather than to a lack of host susceptibility.

Although some literature indicates that black rot infections generally appear within 10 to 14 days after infection $(1,14,24)$, we found that the incubation period can be much longer, particularly as berries begin to acquire ontogenic resistance. Because temperature influences the temporal duration of the incubation period $(1,17)$, a measure of accumulated degree hours (base $0^{\circ} \mathrm{C}$ ) was used to compare incubation periods that occurred under different conditions. A strong linear response was found when the probittransformed percentage of symptomatic berries was regressed against accumulated degree hours. Northover (17) observed a similar relationship between accumulated degree hours (base $7^{\circ} \mathrm{C}$ ) and the incubation period of G. bidwellii on grape leaves. This approach may be useful in future comparisons of black rot development among different regions and years. Improved knowledge concerning the duration of black rot incubation periods, particularly their extension as berries age, has practical implications for pest management advisors. For instance, the appearance of new fruit infections in mid-August in the Finger Lakes Region of New York would probably be the result of infections that occurred during the second or third week of July, rather than in early August as previously thought. This should be considered when attempting to diagnose the precise cause of unexpected control failures.

The data provided in this paper support the concept that a detailed knowledge of a host's period of susceptibility to infection by a given pathogen can be used to design rational fungicide programs for its control. Fortuitously, the period of fruit susceptibility to $U$. necator (powdery mildew) $(5,7)$ is similar to that for G. bidwellii and some evidence suggests a similar period of fruit susceptibility to Plasmopara viticola (downy mildew) (12,25). Thus, it appears that growers should concentrate their most efficacious fungicides and application techniques during this critical period for three of the major grapevine diseases in humid, temperate climates.

\section{ACKNOWLEDGMENTS}

We thank W. E. Fry and B. Reisch for critically reviewing the manuscript; D. G. Riegel, E. Roper, A. Prestia, and K. Pritchard for considerable technical assistance; J. Bernard for statistical advice; J. A. Burr, F. P. Wong, and J. E. Carroll for support; and the NY Wine and Grape Foundation and the Viticulture Consortium-East for funding assistance.

\section{LITERATURE CITED}

1. Cartolaro, P., Pacreau, S., Clerjeau, M., and Maurin, G. 1993. Sensibilité des grappes au black rot: Effet de l'interaction température durée d'humectation sur la gravité de l'infection en conditions contrôlées. B. Dubos, ed. Proc. IOBC/WPRS Working Group "Integrated control in viticulture." 
2. Emele, L. R., Wilcox, W. F., Gadoury, D. M., and Seem, R. C. 1998. Critical period for control of black rot of grape. (Abstr.) Phytopathology 88(suppl.):S25-S26.

3. Ferrin, D. M., and Ramsdell, D. C. 1977. Ascospore dispersal and infection of grapes by Guignardia bidwellii, the causal agent of grape black rot disease. Phytopathology 67:1501-1505.

4. Ferrin, D. M., and Ramsdell, D. C. 1978. Influence of conidia dispersal and environment on infection of grape by Guignardia bidwellii. Phytopathology 68:892-895.

5. Gadoury, D. M., Ficke, A., Seem, R. C., Wilcox, W. F., and Dry, I. 1999. Ontogenic resistance to powdery mildew (Uncinula necator) in grape berries. Proc. 1st Int. Conf. Powdery Mildews. Avignon, France.

6. Gadoury, D. M., Pearson, R. C., Seem, R. C., and Park, E. W. 1997. Integrating the control programs for fungal diseases of grapevine in the Northeastern United States. Vitic. Enol. Sci. 52:140-147.

7. Gadoury, D. M., Seem, R. C., Ficke, A., and Wilcox, W. F. 2001. The epidemiology of powdery mildew on Concord grapes. Phytopathology 91:948-955.

8. Hoffman, L. E. 2001. Management of grape black rot based on disease epidemiology and fungicide activity. Ph.D. thesis. Cornell University, Ithaca, NY.

9. Hoffman, L. E., and Wilcox, W. F. 2002. Utilizing epidemiological investigations to optimize the management of grape black rot. Phytopathology 92:676-680.

10. Hong, J. K., and Hwang, B. K. 1998. Influence of inoculum density, wetness duration, plant age, inoculation method, and cultivar resistance on infection of pepper plants by Colletotrichum coccodes. Plant Dis. 82:1079-1083.

11. Jermini, M., and Gessler, C. 1996. Epidemiology and control of grape black rot in southern Switzerland. Plant Dis. 80:322-325.

12. Kennelly, M. M., Seem, R. C., Gadoury, D. M., Wilcox, W. F., and Magarey, P. 2001. Ontogenic resistance to Plasmopara viticola in grape berries. (Abstr.) Phytopathology 91(suppl.):S47.

13. Kuo, K., and Hoch, H. C. 1995. Visualization of the extracellular matrix surrounding pycnidiospores, germlings, and appressoria of Phyllosticta ampelicida. Mycologia 85:751-771.

14. Kuo, K., and Hoch, H. C. 1996. The parasitic relationship between Phyllosticta ampelicida and Vitis vinifera. Mycologia 88:626-634.

15. Manns, T. F. 1928. Grape disease control in Delaware. Univ. Del. Agric. Exp. Stn. Bull. 154.

16. Neter, J., Kutner, M. H., Nachtsheim, C. J., and Wasserman, W. 1996. Applied Linear Statistical Models. Times Mirror Higher Education Group, Inc., Chicago, IL.

17. Northover, P. R. 1998. The relationship of the number of wetting periods and accumulated degree-days to sporulation of Guignardia bidwellii (Ellis) Viala and Ravaz in vineyards. M.Sc. thesis. Pennsylvania State University, University Park.

18. Ott, R. L. 1993. An Introduction to Statistical Methods and Data Analysis. Duxbury Press, Belmont, CA.

19. Price, B. S. 1892. Black rot of the grape: Life history. Treatment. Tex. Agric. Exp. Stn. Bull. 32:217-231.

20. Ramsdell, D. C., and Milholland, R. D. 1988. Black rot. Pages 15-17 in: Compendium of Grape Diseases. R. C. Pearson and A. C. Goheen, eds. The American Phytopathological Society, St. Paul, MN.

21. Reddick, D. 1911. The black rot disease of grapes. Cornell Univ. Agric. Exp. Stn. Bull. 293:289-364.

22. Scribner, F. L., and Viala, P. 1888. Black Rot (Laestadia bidwellii). Dep. Agric. Bot. Div. Bull. 7.

23. Spotts, R. A. 1977. Effect of leaf wetness duration and temperature on the infectivity of Guignardia bidwellii on grape leaves. Phytopathology 76:1378-1381.

24. Spotts, R. A. 1980. Infection of grape by Guignardia bidwellii-Factors affecting lesion development, conidia dispersal and conidial populations on leaves. Phytopathology 70:252-255.

25. Wilcox, W. F., Riegel, D. G., and Wong, F. P. 1998. Evaluation of fungicide programs for control of downy mildew of grapes, 1997. Fungic. Nematic. Tests 54:111.

26. Xu, X. M., and Robinson, J. D. 2000. Epidemiology of brown rot (Monilinia fructigena) on apple: Infection of fruits by conidia. Plant Pathol. 49:201-206. 